\title{
CERDIK SEPERTI ULAR DAN TULUS SEPERTI MERPATI: BERDASARKAN MATIUS 10:16
}

\author{
Arif Yupiter Gulo ${ }^{1}$ \\ Sekolah Tinggi Teologi Pokok Anggur Jakarta \\ glyupiarif@gmail.com
}

\begin{abstract}
Abstarct: This article discusses the exegetical study of the phrase, "shrewd as snakes and as innocent as doves" according to Matthew 10:16b, the aim to find the meaning from the phrase to apply in the ministry of the servants. This research was developed using qualitative published specifically for the exegetical studies. Through Apparatus study, analysis and syntax, as well as interpretative narrative studies of the text of Matthew 10:16b, the author found that this expression refers to efforts to face the challenges in the ministry which are marked by fact that the servants should have wisdom and integrity so that in the convey the God's kingdom can be realized and reached.
\end{abstract}

Keywords: Shrewd, Innocent, Matthew 10:16

Abstrak: Artikel ini membahas tentang studi eksegesis terhadap ungkapan, "cerdik seperti ular dan tulus seperti merpati" dalam Matius 10:16b, dengan tujuan agar makna yang sesungguhnya dari ungkapan tersebut diperoleh dan oleh para pelayan dapat menerapkan dalam pelayanan. Penelitian ini dikembangkan dengan menggunakan pendekatan kualitatif yang secara spesifik merujuk kepada studi eksegesis. Melalui studi apparatus, analisis dan sintaksis, serta studi narasi interpretative terhadap teks Matius 10:16b, penulis menemukan bahwa ungkapan tersebut mengacu kepada upaya menghadapi tantangan dalam pelayanan yang ditandai bahwa para pelayan sepatutnya memiliki hikmat dan integritas sehingga pekabaran dan pewartaan kerajaan Allah dapat terwujud dan tercapai.

Kata Kunci: Cerdas, Tulus, Matius 10:16 .

\section{PENDAHULUAN}

Rick Warren mengatakan bahwa, Yesus memanggil kita bukan hanya datang kepada Dia, tetapi untuk pergi bagi Dia. $^{2}$ Hal ini terkait dengan memproklamirkan kerajaan-Nya di dalam dunia ini yang dinyatakan dalam Matius 28:20 bahwa,"karena itu pergilah, jadikanlah semua bangsa murid-Ku dan

${ }^{1}$ Arif Yupiter Gulo, M.Th adalah Dosen Teologi Biblika, Perjanjian Baru dan Sosiologi Agama di Sekolah Tinggi Teologi Pokok Anggur Jakarta.

2 Rick Warren, The Purpose Driven Life (Malang: Gandum Mas, 2012), 311. 
baptislah mereka dalam nama Bapa dan Anak dan Roh Kudus.” Namun, dalam tugas panggilan dan pengutusan-Nya itu, tentu menghadapi dan mengalami tantangan baik secara internal maupun eksternal. Menurut Megawani Tonapa bahwa, Dalam tugas dan pelayanan seorang Hamba Tuhan tentulah tidak mudah, tetapi banyak hal dan juga tantangan yang kerap dilalui dalam menghadapi berbagai macam karakter dan sifat anggota jemaat. ${ }^{3}$ Selanjutnya dalam Tesis yang berjudul Relevansi Studi Eksegesis konsep Penderitaan dalam Pelayanan berdasarkan II Korintus 6:1-10 bagi Pengabdian pada Pelayan Tuhan di BNKP Filadelfia Cileungsi mengungkapkan bahwa, adanya tantangan yang datang dari dalam jemaat, yang sering kali terjadi kesalahpahaman dan saling menyalahkan satu dengan yang lain. ${ }^{4}$ Selain itu, dalam artikel Problematika dan Tantangan Gereja Masa Kini diungkapkan bahwa, tantangan gereja masa kini yaitu tantangan lingkungan, sosial, politik, teknologi, tantangan ilmu pengetahuan, serta tantangan kepercayaan atau agama. ${ }^{5}$ Tantangan tentang kepercayaan dan agama ini dalam buku Merayakan Anugerah Tuhan diungkapkan bahwa, adanya nabi-nabi palsu yang menandai dirinya sebagai Mesias. Oleh karena itu nabi-nabi palsu ini sangat kuat dan hebat serta serangan mereka begitu dahsyat, sebab mereka memakai nama Tuhan dalam mewujudkan keinginan mereka untuk merusak dan menghancurkan iman orang percaya. ${ }^{6}$ Nabi-nabi palsu ini dapat digambarkan

3 Megawani Tonapa, "Gaya Hidup Hamba Tuhan (Pendeta) Dalam Menghadapi Tantangan Pelayanan Di Dunia Teknologi Yang Semakin Maju," t.t., 6.

${ }^{4}$ Arif Yupiter Gulo, "Relevansi Studi Eksegesis Konsep Penderitaan dalam Pelayanan Berdasarkan II Korintus 6:1-10 bagi Pengabdian Para Pelayan Tuhan di BNKP Filadelfia Cileungsi" (Tesis Magister Teologi, Jakarta, STT Jaffray, 2016), 4-5.

5 Gerald Wassa, "Problematika dan Tantangan Gereja Masa Kini - Kanwil Kementerian Agama Provinsi Nusa Tenggara Timur," ntt.kemenag.go.id, Kementerian Agama Kantor Wilayah Provinsi Nusa Tenggara Timur, 9 Juni 2017, https://ntt.kemenag.go.id/berita/502696/problematika-dan-tantangan-gerejamasa-kini--\%C2\%A0.

${ }^{6}$ Arif Yupiter Gulo, Merayakan Anugerah Tuhan (Pena Persada, 2020), 79. 
secara umum bahwa umat Tuhan yang mengajarkan ajaran yang keliru dan menyimpang dari Alkitab. Bahkan umat Tuhan yang dikuasai oleh hawa nafsu dunia dengan tidak menjunjung tinggi nilai integritas yang berdasarkan Firman Tuhan. Berdasarkan dengan tantangan ini kerap kali para pelayan-Nya tidak mendapatkan dan mengalami kedamaian sehingga pelayanan tidak berjalan dengan baik bahkan tidak efektif seperti yang sudah direncanakan di dalam program pelayanan. Oleh karena itu, penulis melakukan studi eksegesis Matius 10:16b guna menemukan makna yang sesungguhnya untuk diimplementasikan dalam pelayanan para pelayan gerejawi.

\section{METODE}

Metodologi kualitatif adalah pendekatan analisa mendalam dengan penalaran induktif menggunakan teknik analisa untuk memahami suatu masalah secara subyektif. Tujuan dari metodologi kualitatif ini ialah untuk menemukan hipotesis menghasilkan teori baru. Teori baru ini adalah pengembangan dari teori yang ada (koresponden/koheren) yang merupakan konklusi (preposisi) yang berlaku umum. ${ }^{7}$ Riset kualitatif dimulai dengan tahap refleksi, yaitu peneliti menentukan topik atau permasalahan, termasuk refleksi yang berhubungan dengan peneliti. ${ }^{8}$ Dalam metodologi pendekatan kualitatif ini dengan metode eksegesis sebagai upaya untuk memahami makna teks ${ }^{9}$ dan analisa mendalam yang digabungkan dengan penguraian evaluative. Spiral hermeneutika tidak hanya terjadi pada tingkat makna asli yang dimaksud, di mana pemahaman kita berspiral

\footnotetext{
7 Yakub Tomatala dan Paskalinus Busthan, Penuntun Desain Riset bagi Program Tinggi Teologi (Jakarta: YT Leadership Foundation, 2010), 3.

${ }^{8}$ Andreas B. Subagyo, Pengantar Riset Kuantitatif dan Kualitatif (Bandung: Yayasan Kalam Hidup, 2014), 69.

${ }_{9}$ Subagyo.
} 
ke atas (melalui interaksi dari penyelidikan induktif dan deduktif) menuju makna yang dimaksud suatu perikop, namun juga pada tingkat kontekstualisasi, di mana penerapan kita berspiral ke atas (melalui peralihan dan teologi biblika ke sistematik ke homiletika) menuju suatu pemahaman yang tepat mengenai signifikansi suatu perikop bagi kehidupan Kristen pada hari ini. ${ }^{10}$

\section{HASIL}

Hasil penelitian ini akan memberikan kontribusi kepada para pelayan Tuhan dalam menghadapi tantangan di dalam pelayanan. Berdasarkan teks Matius 10:16 ${ }^{\mathrm{b}}$ ini memaparkan bahwa sebagai pelayan suatu keharusan memiliki hikmat dari Tuhan dan memiliki integritas yang ditandai dengan mutu, sifat, atau keadaan yang menunjukkan kesatuan yang utuh sehingga memiliki potensi dan kemampuan yang memancarkan kewibaan dan kejujuran serta ketulusan di dalam pelayanan. Hasil tersebut merupakan point penting yang akan dijelaskan dalam pembahasan.

\section{PEMBAHASAN}

Dalam Injil Matius nama penulisnya tidak dicantumkan hal ini disebabkan karena semata-mata untuk memperkenalkan Yesus Kristus kepada para pembaca sehingga para pembaca memfokuskan perhatiannya tertuju kepada Yesus (Mat. 23:10-12). Menurut Mark Copeland mengungkapkan bahwa asal mula apostolik dan peringkat kanonik Injil Matius diterima tanpa keraguan oleh gereja mula-mula dan penulis Injil Matius ini bermarga lewi, seorang pemungut cukai dan kemudian

\footnotetext{
10 Selvester Melanton Tacoy, "Analisis Biblika Terhadap Konsep 'Ev Xрıбтw' (Dalam Kristus) Berdasarkan Surat Efesus 1," Jurnal Jaffray 17, no. 2 (1 Oktober 2019): 203, https://doi.org/10.25278/jj.v17i2.337.
} 
menjadi salah satu murid Yesus yang paling awal (Mat. 9:9; Mark. 2:14), dan juga ia menjadi salah satu dari dua belas rasul (Mat. 10:2-3). ${ }^{11}$ Marulak Pasaribu menambahkan bahwa,

Maka semua data yang didapat sudah cukup untuk membuat kesimpulan bahwa penulis Injil Matius adalah Matius, yaitu salah satu dari kedua belas murid Tuhan Yesus. Memang penulis Injil Matius tidak menyebutkan namanya atau siapa penulis kitab tersebut, namun demikian dari sejak semula, gereja mula-mula, khususnya Papias, telah meyakini bahwa Matiuslah penulis Injil Matius. ${ }^{12}$

Selain itu, Injil Matius dapat dikatakan bahwa sulit untuk menetapkan waktu yang pasti tentang tahun penulisan Injil Matius, namun pada umumnya para ahli memperkirakan bahwa Injil Matius ditulis antara tahun 50-60 AD. ${ }^{13}$ Untuk itu, tujuan penulisan Injil Matius untuk menjelaskan bahwa Yesus yang ia beritakan dalam Injil adalah Mesias yang dinubuatkan oleh para nabi dalam PL dan untuk menjawab pertanyaan para pembaca tentang Yesus tersalib, mati dan yang berjanji bahwa Ia akan datang kembali untuk mengokohkan kerajaan Allah di bumi serta mencatat dan meneruskan pengajaran yang disampaikan oleh Yesus kepada para murid dan pengajaran Yesus adalah juga Firman Allah yang berlaku untuk semua generasi dan yang berlaku untuk bangsa-bangsa di luar Yahudi (bdg. Mat. 1:5; 2:1-12; 3:9). Kemudian, ditegaskan bahwa supaya orang Yahudi yang sudah percaya juga terlibat dalam pemberitaan Injil yaitu untuk menjadikan semua bangsa menjadi murid Tuhan Yesus (Mat. 28:19-20). ${ }^{14}$ Dengan demikian bahwa salah satu inti Injil Matius adalah tentang panggilan dan pengutusan dalam

11 Mark A. Copeland, "The Gospel of Matthew Table of Contents" (Executable Outlines, Copyright @ Mark A. Copeland, 2007), https://executableoutlines.com/pdf/matt_so.pdf.

12 Marulak Pasaribu, Eksposisi Injil Sinoptik (Malang: Gandum Mas, 2005), 135.

13 Pasaribu.

14 Pasaribu. 
pemberitaan Injil bukan hanya para murid saja tetapi bagi semua orang yang sudah percaya kepada Tuhan.

\section{Konteks Dekat Matius 10:1-16}

Dalam Matius 10:1-15 menjelaskan tentang pemanggilan dan pengutusan para murid-murid-Nya yang ditegaskan dalam ayat 1 dinyatakan bahwa, "Yesus memanggil kedua belas murid-Nya..." dan kemudian dalam ayat 5 dinyatakan bahwa, "kedua belas murid itu diutus oleh Yesus..."Kedua kata kerja yang dimaksud sangat menarik untuk dicermati bahwa inisiatif dalam melayani bahwa berawal dari kehendak Tuhan bukan kehendak manusia. Kata panggilan dalam hal ini merupakan kata kerja dari bahasa Yunani adalah $\pi \rho o \sigma \kappa \alpha \lambda \varepsilon \sigma \alpha ́ \mu \varepsilon v o \varsigma$ yang artinya memanggil datang; memanggil ke depan. ${ }^{15}$ Demikian juga dengan kata “diutus” dalam bahasa Yunani $\alpha ́ \pi \varepsilon ́ \sigma \tau \varepsilon \imath \lambda \varepsilon v$ yang artinya bahwa mengirim. ${ }^{16}$ Selain itu ungkapan "mengutus" ini diulangi lagi dalam ayat 16a dinyatakan, "Lihat, Aku mengutus kamu seperti domba ke tengah-tengah serigala...” Oleh karena itu, maka patut dikatakan bahwa kedua belas para murid dipanggil dan diutus oleh Yesus dengan tujuan dan sasaran yang jelas untuk menjadi berkat bagi orang lain yang membutuhkan pertolongan dengan ditandai untuk datang kepada domba yang hilang dari umat Israel, menyembuhkan yang sakit dan membangkitkan orang mati serta mengusir setan. Namun, dalam melaksanakan tugas yang mulia itu maka Yesus mengingatkan dengan ungkapan "mengutus kamu seperti domba ditengah-tengah serigala." Kata "serigala" dalam hal ini menunjukkan tantangan yang berat yang ditandai dengan orang jahat yang membahayakan, dan juga bentuk kejahatan dunia ini, yang sarat dengan cobaan, godaan, hawa nafsu, dan

\footnotetext{
15 Hasan Sutanto, Perjanjian Baru Interlinear dan Konkordansi Jilid 2 (Jakarta: LAI, 2010), 635

16 Sutanto. 
segala kejahatan lainnya yang dapat merongrong dan mengganggu umat pilihan Allah yang dapat menghambat pekerjaan Tuhan. ${ }^{17}$ Oleh karena itu, istilah "serigala" melambangkan orang-orang yang menentang pemberitaan Injil dan kekuatan serta kekuasaan mereka begitu kuat dan dahsyat. Mereka menentang pemberitaan Injil disebabkan karena mereka tidak mengenal Allah secara pribadi (Band. Matius 10:18).

\section{Konteks Jauh Matius 10: 17-33}

Dalam konteks ini menjelaskan tentang sumber tantangan yang dihadapi dengan menyatakan bahwa, "tetapi waspadalah terhadap semua orang..." Dalam bahasa Yunani $\alpha \dot{v} \theta \rho \omega ́ \pi \omega v$ yang artinya manusia, umat manusia, (pluralis), saudara atau teman (sapaan yang menunjukkan hubungan dekat atau yang mencela), orang, laki-laki (dewasa), suami, anak (laki-laki) hamba, warga negara. ${ }^{18}$ Berdasarkan pengertian ini menurut Duncan Heaster berpendapat bahwa,

As in 10:16, this is an appeal to not be like sheep in their naivety. The apostles were going to suffer, ultimately. Therefore, they should beware of trusting men too quickly, because the aggression towards them was going to be far greater than they imagined. The apostles likely didn't think that the Jewish religious leadership were as bad as the Lord knew them to be, and they were initially too concerned not to upset them (Mt. 15:12). The "men" of whom they were to "beware" were surely the Pharisees, because elsewhere the Lord teaches the disciples to "beware" of them (Mt. 7:15; 16:6,11,12; Lk. 20:46); and He goes on in this verse to speak of "their synagogues", showing that "men" are in fact the Jewish religious leadership. ${ }^{19}$

Oleh karena itu, waspada kepada semua orang mengacu kepada majelis agama, dan kepada penguasa-penguasa dan raja-raja yang memiliki kuasa untuk memutuskan hukuman bagi siapapun. Tentu, mereka ini memiliki kekuatan yang

\footnotetext{
17 Gulo, "Relevansi Studi Eksegesis Konsep Penderitaan dalam Pelayanan Berdasarkan II Korintus 6:1-10 bagi Pengabdian Para Pelayan Tuhan di BNKP Filadelfia Cileungsi."

18 Sutanto, Perjanjian Baru Interlinear dan Konkordansi Jilid 2,70.

19 Ducan Heaster, Verse by Verse Commentary on Gospel of Matthew (christadelphian matthew gospel commentary verse chapter, 2014), http://heaster.org/Matthew.pdf, 238.
} 
begitu dahsyat oleh karenanya para murid perlu waspada dan hati-hati dalam mengabarkan dan memberitakan Injil. Selain itu, waspada ke semua orang maka Yesus mengingatkan kepada para murid bahwa tidak semua orang memiliki hati yang murni dengan bertopeng sebagai sahabat dan teman karena bisa saja menjadi duri dalam daging yang membahayakan dengan menusuk dari dalam. Itu sebabnya Yesus menegaskan bahwa waspada dan hati-hati serta berjaga-jaga dalam pelayanan sebab tantangan sangat berpotensi datang dengan tiba-tiba. Dalam Matius 7: 15 dinyatakan bahwa waspadalah terhadap nabi-nabi palsu yang datang kepadamu dengan menyamar seperti domba, tetapi sesungguhhnya mereka adalah serigala yang buas.

\section{Teks Matius 10:16}

Pada bagian ini akan dijelaskan tentang teks Matius $10: 16^{\mathrm{b}}$ kritik apparatus, disertai dengan terjemahan penulis, kemudian, struktur atau diagram teks Matius $10: 16^{\mathrm{b}}$ yang merupakan konteks dari Matius 10:16 ${ }^{\mathrm{b}}$ dan diakhiri dengan analisis dan sintaksis dari ayat $16^{\mathrm{b}}$.

\section{Kritik Apparatus}

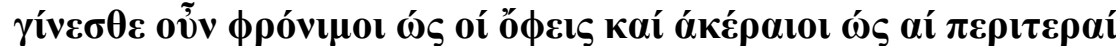

Berbicara tentang apparatus teks terkait dengan pemakaian huruf-huruf A,B,D,C, yang diapit oleh tanda kurung \{\} pada permulaan tiap perangkat varianvarian teks, panitia penyunting telah berusaha untuk menunjukkan seberapa jauh kira-kira tingkat keaslian suatu teks. Kesimpulan diambil atas dasar pertimbangan-pertimbangan internal maupun atas bukti-bukti eksternal, sehingga bacaan tersebut diterima sebagai teks. Huruf A menandakan bahwa teks itu secara yakin dapat dikatakan asli, Sedangkan B menunjukkan adanya sedikit keraguraguan. Huruf $\mathrm{C}$ berarti bahwa tingkat keragu-raguan cukup besar apakah teks 
maupun apparatus berisi bacaan yang tinggi nilainya, sedangkan D memperlihatkan bahwa terdapat tingkat keraguan yang sangat tinggi mengenai bahan bacaan yang dipilih sebagai teks. ${ }^{20}$ Namun, dalam Matius 10:16b penulis tidak menemukan varian teks yang meragukan dalam kritik apparatusnya. Oleh karena itu, teks ini diterima tanpa perdebatan yang signifikan. Akan tetapi teks ini

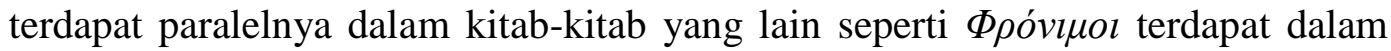
Kisah Para Rasul 20:29; Roma 16:19, dan begitu juga dengan ungkapan $\pi \varepsilon \rho \imath \tau \varepsilon \rho \alpha i ́$ yang mengacu pada Matius 3:16; Markus 1:10 yang menekankan bahwa, "Ia melihat Roh Allah seperti burung merpati turun ke atas-Nya."

\section{Analitycal Greek Leksixon dan Gramcord Grammatical Tag Field and Codes}

\begin{tabular}{|c|c|}
\hline$\Gamma i ́ v \varepsilon \sigma \theta \varepsilon$ & $\begin{array}{l}\text { Kata kerja orang kedua jamak imperfect imperative yang artinya } \\
\text { mengetahui, memahami, memperhatikan. (Hasan Susanto) }\end{array}$ \\
\hline ỡ้ & Kata conjuction, coordinating, inferential yang artinya therefore \\
\hline 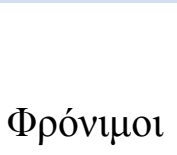 & $\begin{array}{l}\text { Kata adjektif maskulin plural nominative no degree yang artinya } \\
\text { consideration, thoughul, prudent, discreet. }\end{array}$ \\
\hline$\Omega \varsigma$ & Kata partisif komparatif yang artinya, As, as like as, according as. \\
\hline Oí & $\begin{array}{l}\text { kata yang meruapakan maskulin kategori, kasus nominative yang } \\
\text { artinya, itu, ini, ia. }\end{array}$ \\
\hline 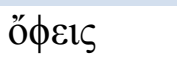 & Kata benda masculine,plural, nominative yang artinya serpent. \\
\hline $\mathrm{K} \alpha 1$ & Kata conjungsi dan coordinating copulative yang artinya and. \\
\hline
\end{tabular}

${ }^{20}$ Alkitab Perjanjian Baru Indonesia-Yunani (Jakarta: LAI, 2002), 1776-1777. 


\begin{tabular}{ll}
\hline Aкépaiov & Kata adjektif maskulin, plural, nominative no degree yang artinya \\
& without mixture of vice or deceit, sincere, artless, blameless. \\
$\Omega \varsigma$ & Kata partisif komparatif yang artinya, As, as like as, according as. \\
$\alpha i ́$ & Kata artikel feminism plural, nominative yang artinya ini, itu, nya, \\
& $i a$. (Hasan Susanto) \\
$\pi \varepsilon \rho ı \tau \varepsilon \rho \alpha i ́$ & Kata benda feminine plural nominative yang artinya doves. \\
\hline
\end{tabular}

\section{Terjemahan Peneliti}

Oleh karena itu kalian harus menjadi bijaksana seperti ular dan tidak bernoda seperti merpati

\section{Terjemahan TB-LAI}

Sebab itu hendaklah cerdik seperti ular dan tulus seperti merpati

\section{Terjemahan NIV}

therefore as shrewd as snakes and as innocent as doves

\section{Terjemahan KJV}

Be ye therefore wise as serpents, and harmless as doves

\section{Penilaian}

Secara prinsip bahwa tidak ada perbedaan antar terjemahan peneliti dengan terjemahan yang lain. Kendati terdapat kata-kata atau struktur yang berbeda. Namun, semuanya sama dalam memberikan pemahaman dan pengertian 
yang mengacu kepada upaya yang ditempuh para murid-murid-Nya untuk menghadapi tantangan yang dirasakan dalam pelayanan.

\section{Diagram}

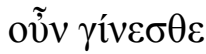

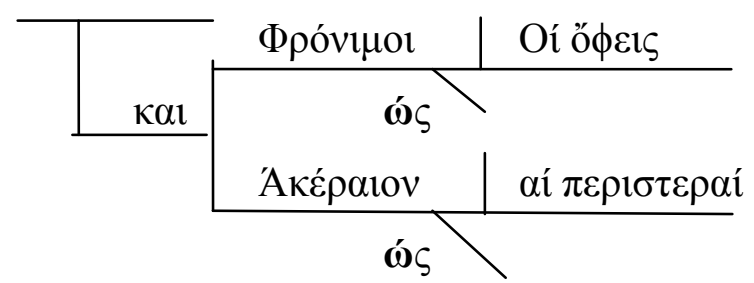

Diagram di atas diadopsi dari buku leedy yang berjudul New Testament Diagrams. Berdasarkan diagram di atas maka jelas bahwa kedua kata kerja yang ditandai dengan ungkapan perintah yang suatu keharusan dimiliki dan dilakukan. Itu sebabnya diteruskan dengan kedua kata sifat tersebut yang menjadi acuannya adalah kedua kata benda. Akan tetapi ditentukan dengan pemakaian kata partisif komparatif yang menunjukkan bahwa kedua kata sifat harus sesuai dengan kata benda yang dimaksud. Dalam hal ini menurut Marulak mengungkapkan bahwa

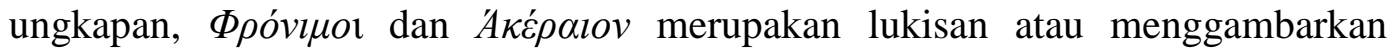
sedangkan ungkapan ő $\phi \varepsilon ı \varsigma$ dan $\pi \varepsilon \rho l \sigma \tau \varepsilon \rho \alpha i$ adalah merupakan sifat perbandingan. ${ }^{21}$ Oleh karena itu, setiap ungkapan itu menunjukkan keterkaitan antara satu dengan yang lain. Sebab, jika tidak ada kaitannya maka tentu setiap kata tersebut tidak akan ada manfaatnya. Itu sebabnya semua kata tersebut perlu untuk dieksegesis dalam menemukan makna yang sesungguhnya.

\section{Struktur Tafsiran}

○ Oleh sebab itu hendaklah

- Cerdas seperti ular

21 Pasaribu, Eksposisi Injil Sinoptik. 
○ Tulus seperti merpati

Tafsiran Matius 10:16b

Untuk mengetahui dan memahami ayat $16 \mathrm{~b}$ tentu tidak dapat dipisahkan dari urgensinya tentang pekabaran dan pewartaan kerajaan Allah bagi umat manusia supaya setiap orang percaya kepada Yesus Kristus. Namun dalam pekabaran dan pewartaan keselamatan tersebut tidak semudah yang dibayangkan seperti dalam melakukan pekerjaan yang lain, tentu merupakan pekerjaan yang sulit dan berat sebab berbagai tantangan yang dihadapi.

\section{Oleh Sebab itu Hendaklah}

Ketika Yesus mengutus para murid-murid-Nya maka Ia juga mengingatkan sikap yang ditempuh dalam menghadapi bahaya. Dalam bahasa

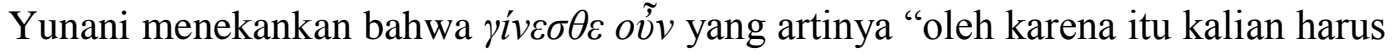
menjadi." Hal ini menjelaskan bahwa para murid-murid-Nya mengetahui dan memahami serta memperhatikan ${ }^{22}$ sikap yang tepat jika berada ditengah-tengah pelayanan tatkala menghadapi tantangan. Menurut John bahwa, Be is more exactly become, get to be, implying that they are not so now. ${ }^{23}$ Artinya bahwa para murid bisa beradaptasi atau dapat menyesuaikan diri tanpa harus sama seperti orang lain. Oleh karena itu, maka hal ini menunjukkan bahwa Yesus mengharapkan ada perubahan karakter yang dimiliki oleh para murid dengan perubahan yang signifikan dalam diri mereka untuk menghadapi tantangan dalam pelayanan.

\footnotetext{
22 Hasan Sutanto, Perjanjian Baru Interlinear dan Konkordansi Jilid 1 (Jakarta: LAl, 2010), 157.

23 Johan A. Broadus, Commentary On the Gospel of Matthew (Philadelphia: America Baptist Publication Society, 1920), 224. 


\section{Cerdik seperti Ular}

Yesus menggambarkan kepada para murid-murid-Nya upaya yang ditempuh dalam menghadapi tantangan yaitu harus cerdik dan berpikiran sehat, bijaksana dengan sesungguhnya, Mat. 7:24; 10:16;24:45; 25:2, 4, 8, $9 .{ }^{24}$ Itu sebabnya, Paulus menegaskan bahwa, "karena itu, perhatikan dengan seksama, bagaimana kamu hidup, janganlah seperti orang bebal, tetapi seperti orang arif." (Kol. 5:15). Oleh karena itu, bijaksana dalam hal ini yaitu menggunakan akal budinya (pengalaman dan pengetahuannya); arif; tajam pikiran; pandai dan hatihati (cermat, teliti, dan sebagainya) apabila menghadapi kesulitan. ${ }^{25}$ Dalam Mazmur 119:66 menegaskan bahwa, Ajarkanlah kepadaku kebijaksanaan dan pengetahuan yang baik, sebab aku percaya kepada perintah-perintah-Mu. Itu sebabnya Salomo menyatakan bahwa, maka berikanlah kepada hamba-Mu ini hati yang faham menimbang perkara untuk menghakimi umat-Mu dengan dapat membedakan antara yang baik dan jahat, siapakah yang sanggup menghakimi umat-Mu yang sangat besar ini? (1 Raja-raja 3:9). Lalu kemudian Tuhan menjawab Salomo dinyatakan bahwa, maka sesungguhnya Aku melakukan sesuai dengan permintaanmu itu, sesungguhnya Aku memberikan kepadamu hati yang penuh hikmat dan pengertian, sehingga engkau, dan sesudah engkau takkan bangkit seorang pun seperti engkau. (1 Raja-raja 3:12). Menurut Collins Bible Dictionary mengungkapkan bahwa,

Wisdom, a term in the Hebrew Bible (OT) standing for many things ranging from the technical skill of the artisan (Exod. 36:8) to the art government (1 Kings 3:12, 28). It also designates simple cleverness (2

24 Vine's Complete Expository Dictionary of Old and New Testament Word (New York: Thomas Nelson Publisher, 1985), 679.

25 Pusat Pembinaan dan Pengembangan Bahasa, Kamus besar bahasa Indonesia (Departemen Pendidikan Kan Kebudayaan, Indonesia, 1988), https://books.google.co.id/books?id=ZaPmAAAAMAAJ. 
Sam. 14:2), especially the pratical skill of coping with life (Prov. $1 ; 5 ; 11$; 14), and the pursuit of a lifestyle of proper ethical conduct (Prov. 2:9-11) and throughout). Wisdom is also seen as belonging properly to God (Job 28), associated with creation (Prov. 8:22-31), and even identified with the Torah or Law (Ecclus. 24:23). ${ }^{26}$

Oleh karena itu, kecerdasan tersebut melambangkan seperti ular. Dalam

buku Vine's diungkapkan bahwa,

The characteristics of the "serpent" as alluded to in sciptura are mostly evil (thought Matt. 10:16 refers to its caution in avoiding danger); its treachery, Gen. 49:17; 2 Cor. 11:3; its venom, Ps 58:4; 1 Cor. 10:9; Rev 9:19; its skulking Job 26:13; its murderous proclivities, e.g., Ps 58:4; Prov. 23:32; Eccl. 10:8, 11; Amos 5:19; Mark. 16:18; Luke 10:19; the Lord used the word metaphorically of the scribes and Pharises, Matt. 23:33 (cf. echidna, "Viper," in Matt. 3:7; 12:34). The general aspects of its evil character are intimated in the Lord's rhetorical question in Matt. 7:10 and Luke 11:11. Its characteristics are contrated in the archadversary of God and man, the Devil, metaphorically described as the serpent, 2 Cor. 11:3; Rev12:9, 14, 15; 20:2. The brazen "serpent" lifted up by Moses was symbolical of the means of salvation provided by God, in Christ and His vicarious death under the divine judgment upon sin, John 3:14. While the living "serpent" symbolizes sin in its origin, hatefulness, and deadly effect, the brazen "serpent" symbolized the bearing away of the curse and the judgment of sin; the metal was itself figurative of the righteousness of God's judgment. $^{27}$

Namun, dalam Bible Dictionaries diungkapan bahwa, This word is used symbolically of a deadly, subtle, malicious enemy (Luke 10:19). ${ }^{28}$ Menurut Charles Huddon mengatakan,The weapons of Christiansare that they are weaponless. They are to be prudent, discreet, “wise as serpents, ”but they are to

${ }^{26}$ Paul J. Achtemeier, Harper Collins Bible Dictionary (New York: Harper Collins Publishing Inc, 1996), 1214

${ }^{27}$ Vine's Complete Expository Dictionary of Old and New Testament Word, 562.

28 M.G. Easton, "Easton's Bible Dictionary," biblestudy.com, Bible Study, t.t., https://www.biblestudytools.com/dictionaries/eastons-bible-dictionary/serpent.html, 11/08/2020. 
be loving, peaceful, “harmless as doves."29 Selanjutnya Duncan Heaster mengatakan,

Wise as serpents. The Lord may not be using the snake here as a symbol of sin or sinful people. He may simply be alluding to the way that when a snake moves into a new area, it is cautious, uses camouflage to blend in, spies out opportunities, doesn't act hastily and doesn't immediately go for what looks the easiest target. ${ }^{30}$

Bahkan, William Bruce berpendapat bahwa, The serpent is in consequence the emblem of circumspection, which man exercises through the sensual principle of his nature. ${ }^{31}$ Selain itu,

Serpents show great caution and skill in avoiding danger. The Egyptian hieroglyphics use the serpent as the symbol of wisdom. We may understand that they were to be prudent in the recognition of danger, and in the choice of means for oppos ing or escaping it in general as to their be haviour when in danger. But such prudent regard for self-preservation is very apt to be accompanied, in men as in serpents, with the tricks of low cunning. ${ }^{32}$

Dengan demikian, penulis menyimpulkan bahwa ungkapan cerdik dalam hal ini yaitu bijaksana yang melambangkan seperti ular dengan hati-hati dalam menyelamatkan diri dari bahaya sehingga pekabaran dan pewartaan Injil dapat tercapai dan terwujud.

\section{Tulus seperti Merpati}

Yesus bukan hanya menegaskan tentang sikap yang bijaksana dan cerdas dalam menghadapi tantangan tetapi juga Ia menegaskan tentang upaya untuk selalu menjunjung tinggi ketulusan, kesucian hidup, dan tidak tercemar. Dalam hal ini Menurut Vine's mengungkapkan bahwa,

\footnotetext{
${ }^{29}$ Charles H. Spurgeon, Commentary on Matthew : The Gospel of the Kingdom (Edinburgh: Banner of Truth Trust, 2010), 81-82.

30 Heaster, Verse by Verse Commentary on Gospel of Matthew, 357.

31 William Bruce, Commentary On The Gospel According To ST. Matthew (London, 1886), https://newchristianbiblestudy.org/bundles/ncbsw/translation/commentary-on-matthew-bruce.pdf, 176.

32 Broadus, Commentary On the Gospel of Matthew, 224.
} 
Primarly denotes "unpunished" (a negative, theo, "a penalty"); then "innocent," Matt. 27:4, "innocent blood," i.e., the blood of an "innocent" person, the word "blood" being used both by synecdoche (a part standing for the whole), and by metonymy (one thing standing for another), i.e., for death by execution (some mss. Have dikaion, "righteous") v, where Pilate speaks of Him self as "innocent.",33

Untuk itu, maka ungkapan óképaıoı mengacu kepada orang tulus yang ditandai dengan sungguh dan bersih hati (benar-benar keluar dari hati yang suci); jujur; tidak pura-pura; tidak serong, tulus hati; tulus ikhlas. ${ }^{34}$ Itu sebabnya John mengatakan bahwa, The word rendered harmless, better simple (margin Kev.Ver.) signifies literally unmixed, and hence pure (as pure wine, pure gold), uncorrupted, and so guileless, sincere. ${ }^{35}$ Oleh karena itu, maka hal ini dapat dikatakan bahwa tidak munafik, tidak mencari keuntungan dalam melayani, tidak melukai dan tidak menyakiti orang lain tetapi menolong dan membantu serta berkorban demi orang lain bahkan menjunjung tinggi nilai-nila kasih yang sesungguhnya dan orang yang tidak tercemar serta tidak serupa dengan dunia ini seperti pernyataan Paulus dalam Roma 12:1 dinyatakan bahwa, "janganlah kamu serupa dengan dunia ini, tetapi berubah oleh pembaharuan budimu..."Artinya bahwa akal dan pikirannya tidak tercemar oleh dosa sehingga tidak menjadi batu sandungan dalam pelayanan sebab jika menjadi batu sandungan maka berpotensi yang besar untuk menghambat pekerjaan Tuhan sehingga tidak dapat terlaksana dan terwujud dengan baik. Itu sebabnya ketulusan ini diibaratkan seperti merpati yang dalam bahasa Yunani adalah $\pi \varepsilon \rho \imath \sigma \tau \varepsilon \rho \alpha i$ artinya merpati yang melambangkan sifat damai dan bersih. ${ }^{36}$ Selain itu ditegaskan bahwa merpati putih, lambang

\footnotetext{
33 Vine's Complete Expository Dictionary of Old and New Testament Word, 327.

34 Pusat Pembinaan dan Pengembangan Bahasa, Kamus besar bahasa Indonesia.

35 Broadus, Commentary On the Gospel of Matthew, 224-225.

36 Sutanto, Perjanjian Baru Interlinear dan Konkordansi Jilid 2, 594.
} 
perdamaian, karena sifatnya yang elok dan bulunya yang melambangkan kesucian. ${ }^{37}$ Oleh karena itu, kata "merpati" menggambarkan orang yang membawa damai.

Damai artinya tidak ada permusuhan dan perselisihan serta pertikaian. Bahkan, Paulus S Wijaya mengusulkan makna "damai" dalam konotasi positif. Seharusnya perdamaian bukan hanya dipandang sebagai keadaan tenang dan tidak ada perang namun dipahami sebagai situasi di mana hal tertentu yang mendukung perdamaian dengan sengaja diadakan. Di sini, segala bentuk kekerasan sehingga perdamaian sungguh-sungguh diwujudkan. ${ }^{38}$ Dengan demikian bahwa bukan hanya sebagai pelayan yang tidak bernoda tetapi pembawa damai sejahtera bagi umat manusia. Namun, terkait dengan damai sejahtera itu maka Paulus menegaskan bahwa, Sebab itu marilah kita mengejar apa yang mendatangkan damai sejahtera dan yang berguna untuk saling membangun. (Roma 14:19).

\section{KESIMPULAN}

Cerdik seperti ular dan tulus seperti merpati merupakan gambaran tentang upaya yang ditempuh dalam menghadapi tantangan dan rintangan dalam pelayanan. Itu artinya bahwa sebagai pelayan suatu keharusan memiliki hikmat dan bijaksana serta tidak bernoda dan tidak dicemari dengan dunia bahkan pembawa damai sejahtera bagi sesama umat manusia serta memiliki integritas yang sejati. Dengan demikian kendati tantangan yang dihadapi memiliki kekuatan dan serangannya begitu dahsyat namun dapat dihadapi dan dilewati sehingga tidak

37 Yogi Triyuniardi, "Cerdik Seperti Ular Tulus Seperti Merpati," artikel.sabda.org, E-Artikel: Situs Artikel Kristen, t.t., https://artikel.sabda.org/cerdik_seperti_ular_tulus_seperti_merpati.

38 Oktavianus Heri Prasetyo Nugroho, "Meretas Damai Di Tengah Keberagaman: Mengembangkan Pendidikan Kristiani untuk Perdamaian dalam Perspektif Multikulturalisme," Gema Teologi; Vol 38 No 2 (2014): Gema Teologi, 16 Oktober 2014, http://journal-theo.ukdw.ac.id/index.php/gema/article/view/185. 
tawar hati bahkan justru memiliki pengharapan di dalam Tuhan. Dalam hal ini

Paulus menegaskan bahwa oleh kemurahan Allah aku menerima pelayanan ini.

Karena itu kami tidak tawar hati. (2 Kor. 4:1)

\section{DAFTAR PUSTAKA}

Achtemeier, Paul J. Harper Collins Bible Dictionary. New York: Harper Collins Publishing Inc, 1996.

Alkitab Perjanjian Baru Indonesia-Yunani. Jakarta: LAI, 2002.

Broadus, Johan A. Commentary On the Gospel of Matthew. Philadelphia: America Baptist Publication Society, 1920.

Bruce, William. Commentary On The Gospel According To ST. Matthew. London, 1886.

https://newchristianbiblestudy.org/bundles/ncbsw/translation/commentaryon-matthew-bruce.pdf.

Copeland, Mark A. "The Gospel of Matthew Table of Contents." Executable Outlines, Copyright (c) Mark A. Copeland, 2007. https://executableoutlines.com/pdf/matt_so.pdf.

Easton, M.G. "Easton's Bible Dictionary." Biblestudy.com. Bible Study, t.t. https://www.biblestudytools.com/dictionaries/eastons-bibledictionary/serpent.html.

Gulo, Arif Yupiter. Merayakan Anugerah Tuhan. Pena Persada, 2020. 79.

—. "Relevansi Studi Eksegesis Konsep Penderitaan dalam Pelayanan Berdasarkan II Korintus 6:1-10 bagi Pengabdian Para Pelayan Tuhan di BNKP Filadelfia Cileungsi.” Tesis Magister Teologi, STT Jaffray, 2016. 4-5.

Heaster, Ducan. Verse by Verse Commentary on Gospel of Matthew. christadelphian matthew gospel commentary verse chapter, 2014. http://heaster.org/Matthew.pdf.

Nugroho, Oktavianus Heri Prasetyo. "Meretas Damai Di Tengah Keberagaman: Mengembangkan Pendidikan Kristiani untuk Perdamaian dalam Perspektif Multikulturalisme." Gema Teologi; Vol 38 No 2 (2014): Gema Teologi, 16 Oktober 2014. http://journaltheo.ukdw.ac.id/index.php/gema/article/view/185.

Pasaribu, Marulak. Eksposisi Injil Sinoptik. Malang: Gandum Mas, 2005. 
Pusat Pembinaan dan Pengembangan Bahasa. Kamus besar bahasa Indonesia. Departemen Pendidikan dan Kebudayaan, Republik Indonesia, 1988. https://books.google.co.id/books?id=ZaPmAAAAMAAJ.

Spurgeon, Charles H. Commentary on Matthew: The Gospel of the Kingdom. Edinburgh: Banner of Truth Trust, 2010.

Subagyo, Andreas B. Pengantar Riset Kuantitatif dan Kualitatif. Bandung: Yayasan Kalam Hidup, 2014. 69.

Sutanto, Hasan. Perjanjian Baru Interlinear dan Konkordansi Jilid 1. Jakarta: LAI, 2010. 108.

. Perjanjian Baru Interlinear dan Konkordansi Jilid 2. Jakarta: LAI, 2010. 585.

Tacoy, Selvester Melanton. "Analisis Biblika Terhadap Konsep ' $\epsilon \mathrm{V}$ X $\rho \iota \tau \omega$ ' (Dalam Kristus) Berdasarkan Surat Efesus 1.” Jurnal Jaffray 17, no. 2 (1 Oktober 2019): 203. https://doi.org/10.25278/jj.v17i2.337.

Tomatala, Yakub, dan Paskalinus Busthan. Penuntun Desain Riset bagi Program Tinggi Teologi. Jakarta: YT Leadership Foundation, 2010. 3.

Tonapa, Megawani. “Gaya Hidup Hamba Tuhan (Pendeta) Dalam Menghadapi Tantangan Pelayanan Di Dunia Teknologi Yang Semakin Maju,” t.t., 6.

Triyuniardi, Yogi. "Cerdik Seperti Ular Tulus Seperti Merpati.” Artikel.sabda.org. E-Artikel: Situs Artikel Kristen, t.t. https://artikel.sabda.org/cerdik_seperti_ular_tulus_seperti_merpati.

Vine's Complete Expository Dictionary of Old and New Testament Word. New York: Thomas Nelson Publisher, 1985.

Warren, Rick. The Purpose Driven Life. Malang: Gandum Mas, 2012. 311.

Wassa, Gerald. "Problematika dan Tantangan Gereja Masa Kini - Kanwil Kementerian Agama Provinsi Nusa Tenggara Timur.” Ntt.kemenag.go.id. Kementerian Agama Kantor Wilayah Provinsi Nusa Tenggara Timur, 9 Juni 2017. https://ntt.kemenag.go.id/berita/502696/problematika-dantantangan-gereja-masa-kini--\%C2\% A0. 